\title{
Lower farrowing rate in female pigs associated with higher outdoor temperatures in humid subtropical and continental climate zones in Japan
}

\author{
R. Iida, Y. Koketsu' \\ School of Agriculture, Meiji University, Kawasaki, Japan.
}

\begin{abstract}
The aim of this study was to examine the respective associations between farrowing rate and either environmental or production factors in female pigs in commercial herds. We analyzed 264,057 records of females serviced in 101 Japanese herds located either in humid subtropical or humid continental climate zones. Outside environment data were obtained from 21 weather stations located close to the respective herds. Mean daily average temperatures (Tavg) and relative humidity for the 21-day pre-service periods for each female were coordinated with that female's performance data. Generalized linear models were applied to the data for each parity. Overall average farrowing rate $( \pm \mathrm{SE})$ was $85.2 \pm 0.07 \%$, and the mean daily average temperature (range) and relative humidity were 15.0 $(-8.1 \text { to } 32.7)^{\circ} \mathrm{C}$ and $68.1(19-99) \%$, respectively. Higher Tavg was associated with lower farrowing rate in all parity groups $(\mathrm{P}<0.05)$. Farrowing rates of females in all parities decreased non-linearly as pre-service Tavg increased from 15 to $30^{\circ} \mathrm{C}(\mathrm{P}<0.05)$. Decreases ranged from $83.1-71.3 \%$ in parity 1 to $85.1 \%$ to $80.0 \%$ in parity 5 . Also, delayed gilt age at first-mating, re-servicing, and a weaning-to-first-mating interval of 7 days or longer were associated with lower farrowing rate in either gilts or sows, or both $(\mathrm{P}<0.05)$. However, there were no associations between farrowing rate and either pre-service humidity $(\mathrm{P} \geq 0.09)$ or lactation length $(P \geq 0.06)$ in any parity. Therefore, we recommend that producers pay particular attention to females at risk of having reproductive failure, and apply cooling systems to prevent a decrease in farrowing rate for heat-stressed female.
\end{abstract}

Keywords: heat stress, humidity, porcine fertility, seasonality.

\section{Introduction}

Heat stress in female pigs can reduce farrowing rate (Bertoldo et al., 2012), which can lead to increases in nonproductive sow days and reduced breeding productivity in breeding herds (Dial et al., 1992). A recent study conducted mostly in a Mediterranean climate zone has shown that the greatest impact on farrowing rate was heat stress related to high outdoor temperature 21 to 14 days before service (Bloemhof et al., 2013). However, no research has quantified the association between commercial herd farrowing rates and pre-service temperatures in humid subtropical and continental climate zones, where humidity is relatively high. Some limited research has been carried out in other climate zones. For example, Lewis and Bunter (2011) found no effect of humidity on reproductive performance in an Australian climate zone characterized by low humidity. However, they did not examine the relationship between farrowing rate and temperature by parity. Such information about quantified associations between farrowing rate and climatic factors by parity could help veterinarians or producers to predict how farrowing rates are likely to decrease by parity, based on the information about outdoor temperatures in local weather news.

In addition to environmental factors, there are three other factors that can be negatively associated with farrowing rate. A reduced farrowing rate has been associated with a higher gilt age at first-mating, shorter lactation length and prolonged weaning-to-first-mating interval (WMI; Takai and Koketsu, 2007; Bertoldo et al., 2009). Furthermore, few studies have compared farrowing rates of females serviced in different months to examine the associations between farrowing rate and environmental factors, taking account of these production factors. Therefore, the aims of this study were to assess seasonal variation in farrowing rate in a model that included production factors associated with farrowing rate in humid subtropical and continental climate zones, and also to quantify the associations between farrowing rate and either outdoor environmental temperature or humidity.

\section{Materials and Methods}

The present study was designed as a retrospective cohort study coordinating reproductive performance data in commercial herds with environmental information in a pre-service period.

Herds

One hundred and three breeding pig producers in Japan that use the PigCHAMP recording system (PigCHAMP, Ames, IA, USA) were requested to mail their data files to Meiji University in 2010. By August 31,2010 , data files were received from all 103 breeding herds, but data from two herds were excluded from the present study because they were producing only purebred pigs.

The remaining 101 commercial breeding herds were located throughout Japan. The herds use natural or mechanical ventilation in their farrowing, breeding and gestation barns, and the lactation and gestation diets are formulated using imported corn and soybean meal. Drip 
cooling systems are mainly used in these commercial herds, whereas a few producers use cool cell ventilation. Approximately $90 \%$ of the herds use artificial insemination; double or triple inseminations of females during an estrous period were recommended in breeding management. In addition, about $70 \%$ of the herds use real-time ultrasound apparatus, with the remaining herds using echo or Doppler ultrasound apparatus at approximately day 30 of gestation. Females in the herds were mainly crossbreds between Landrace and Large White, which were either purchased replacement gilts from national or international breeding companies, or they were replacement gilts home-produced through internal multiplication programs using grandparents purchased from national or international breeding companies. The breeding stocks in the national breeding companies were originally imported from the USA or Europe during the latter half of the 20th century, and have been improved in Japan.

Data for herd measurements were abstracted from the 101 herd data files, for three 1 -year periods (January to December) from 2007 to 2009. Mean ( \pm SEM) herd size was $428 \pm 57.3$ females, with a range between 50 and 3640 females. Mean pigs weaned per mated female per year (range) was 22.6 \pm 0.19 (15.8-26.4) pigs, mean lactation length was $22.6 \pm 0.21$ (15.4-28.9) days, and mean farrowing rate was $83.5 \pm$ $0.57(61.9-96.1) \%$.

\section{Reproductive performance data exclusion criteria}

Data for parity 0-5 females that were serviced in 2007-2009 were extracted from the PigCHAMP recording system. Parity 6 or higher females were not used in the present study because large numbers of these sows were voluntarily culled for old age (Sasaki and Koketsu, 2011). The initial dataset contained 62,001 service records for gilts and 215,359 service records for sows. The data included re-service records.

Records of gilt ages at first-mating less than 160 days or more than 400 days were considered extreme and were excluded from Dataset 1 (2440 records; Hoving et al., 2011). Also, records for sows were excluded from Dataset 2 under the following criteria: lactation length was either 0-9 days or 42 days or longer (1304 records; Hoving et al., 2011); WMI was 36 days or longer (2776 records; Hoving et al., 2011). Furthermore, sow records were also removed if the number of pigs weaned was either three pigs or fewer (1634 records; Stevenson and Britt, 1981) or if it was greater than the mean $+3 \times$ SD (17 pigs or more; 5149 records; Bloemhof et al., 2013). These record removals left 59,061 gilt records and 204,496 sow records that were used for further analyses.

\section{Definitions and categories}

A gilt was defined as a female pig that had entered a herd but had not yet farrowed, and a sow was a female pig that had farrowed at least once (PigCHAMP, 1996). A mating was defined as any single insemination of a female during estrus, and a service included one or more mating events in the estrus. A re-service was defined as when more than one service event occurred within a parity.

Female records were categorized into two "number of service" groups: first-service and re-service. Two WMI groups were also formed for sow records: WMI 0-6 days, and WMI 7 days or higher.

\section{Climate data}

Outdoor environmental data from 2007 to 2009 were downloaded from the climate statistics of 21 weather stations from the Japan Meteorological Agency (JMA, 2014). These weather stations were located in the prefectural government office cities of the 21 prefecture districts where the studied herds were located. The weather stations were located between latitude $30-45^{\circ} \mathrm{N}$ and longitude $130-145^{\circ} \mathrm{E}$. Based on the Köpper climate classification (Peel et al., 2007), the herds were located in either humid subtropical climate zones (96 herds) or humid continental climate zones ( 5 herds). Mean distance $( \pm$ SEM) from each herd to the relevant weather station was $44.2 \pm 2.71 \mathrm{~km}$, ranging from 1 to $110 \mathrm{~km}$. A correlation of 0.9 has been estimated between on-farm temperature data and weather station temperature in the USA, even for weather stations more than $300 \mathrm{~km}$ away from the farm (Freitas et al., 2006). In addition, previous studies have used climate data from weather stations at similar distances from the farms as in our study. For example, in a study, the average distance between farm and weather station was $117 \mathrm{~km}$ (range in distance: 25 to $237 \mathrm{~km}$; Bloemhof et al., 2013).

Mean values of daily average temperatures (Tavg) and daily average relative humidity for the 21-day pre-service period of each female were coordinated with respective performance data from the PigCHAMP recording system. This period was chosen based on recent reports which indicate that the environmental conditions during the pre-service period are critical for reproductive performance. For example, a study showed that heat stress from 21 to 14 days before the first insemination has the largest effect on farrowing rate (Bloemhof et al., 2013). Also, in an earlier study we found that high humidity amplifies the negative effect of high temperature during the 21-day pre-service period on total number of pigs born (Iida and Koketsu, 2014). A further reason for selecting this period is that the 21-day pre-service period covers a large part of the sow lactation period.

\section{Statistical analysis}

All statistical analyses were conducted using SAS version 9.3 (SAS Institute Inc., Cary, NC, USA). A generalized linear model was applied to binary outcome, i.e., whether or not a female farrowed ( 1 or 0$)$, by using the GLIMMIX procedure with a logit function. The Ilink (invers link function) was used to convert the logit to a probability. Statistical models were constructed by parity in order to avoid the 3-level hierarchy of individual service records within a female, and females 
within a herd. Two statistical models were created for each parity; in Model 1, farrowing rate was compared between six 2-month service groups (January-February, March-April, May-June, July-August, SeptemberOctober and November-December). Model 2 was constructed to examine the associations between farrowing rate and outdoor environmental factors such as Tavg and humidity.

The six 2-month service groups and the environmental factors of Tavg and humidity were included as fixed effect variables in Models 1 and 2, respectively. Indicial models for gilts also included gilt age at first-mating and number of services. In addition, the following factors were used when sows were analyzed: number of services, lactation length and WMI. The number of pigs weaned was included in the sow model because producers would have fostered piglets on to fertile sows or nurse sows (Bertoldo et al., 2009). All the continuous explanatory variables (i.e., age at first-mating, lactation length, number of pigs weaned and WMI) were centered at their grand mean values. Also, all the models included a random herd effect and a random serviced-year effect within each herd. The quadratic expressions of environmental factors were examined. Non-significant variables and non-significant quadratic expressions were eliminated from models $(\mathrm{P} \geq$
0.05). To check the adequacy of the model assumptions, the normality of the random effects was evaluated by visual inspection of normal probability plots (Littell et al., 2006).

To assess the variance in farrowing rate that could be explained by the herd effect, the intraclass correlation coefficient (ICC) was calculated by the following equation (Dohoo et al., 2009):

ICC (records within the same herd) $=\sigma_{v}^{2} /\left(\sigma_{v}^{2}+\sigma_{u}^{2}+\left(\pi^{2} / 3\right)\right)$,

in which $\sigma_{v}^{2}$ is the between-herd variance, $\sigma_{\mathrm{u}}^{2}$ is the between-year variance and $\pi^{2} / 3$ is the assumed variance at the individual record level.

\section{Results}

Descriptive statistics of reproductive performance for gilts and sows are shown in Table 1 . Farrowing rates of gilts and sows were 82.3 and $86.0 \%$, respectively, and the overall farrowing rate $( \pm \mathrm{SE})$ of females was $85.2 \pm 0.07 \%$. Mean values (ranges) of daily average temperatures and daily average relative humidity were $15.0(-8.1 \text { to } 32.7)^{\circ} \mathrm{C}$ and $68.1(19-99) \%$, respectively.

Table 1. Reproductive data for females serviced from 2007 to 2009 in 101 herds.

\begin{tabular}{lrrrc}
\hline \multicolumn{1}{c}{ Measurements } & $\mathrm{N}$ & Mean \pm SEM & \multicolumn{2}{c}{ Range } \\
\cline { 3 - 5 } & & & Minimum & Maximum \\
\hline Gilts & & & 1 & 13 \\
$\quad$ Number of service & 59,561 & $1.1 \pm 0.01$ & 160 & 400 \\
$\quad$ Age at first-mating, days old & 59,561 & $247.6 \pm 0.11$ & & 5 \\
Sows & & & 1 & 8 \\
$\quad$ Parity & 204,496 & $2.8 \pm 0.01$ & 1 & 16 \\
$\quad$ Number of service & 204,496 & $1.1 \pm 0.01$ & 4 & 41 \\
$\quad$ Number of pigs weaned, pigs & 204,496 & $21.5 \pm 0.01$ & 10 & 35 \\
Lactation length, days & 204,496 & $6.3 \pm 0.01$ & 0 & \\
Weaning-to-first-mating interval, days & 204,496 & & &
\end{tabular}

Table 2 shows the farrowing rates of females serviced at different parities in different seasons, and daily average temperatures and daily average relative humidity for each 2-month group. The lowest farrowing rate was for females serviced in July-August for all parities $(\mathrm{P}<0.05)$. These farrowing rates of females in parities $0-5$ were 2.8 , $6.9,5.4,4.9,4.3$ and $4.3 \%$ lower than the respective farrowing rates of females in March-April.

Table 2. Farrowing rates (\%, SE) of females in different parity females serviced in different seasons, and daily average temperatures and relative humidity for six 2-month groups

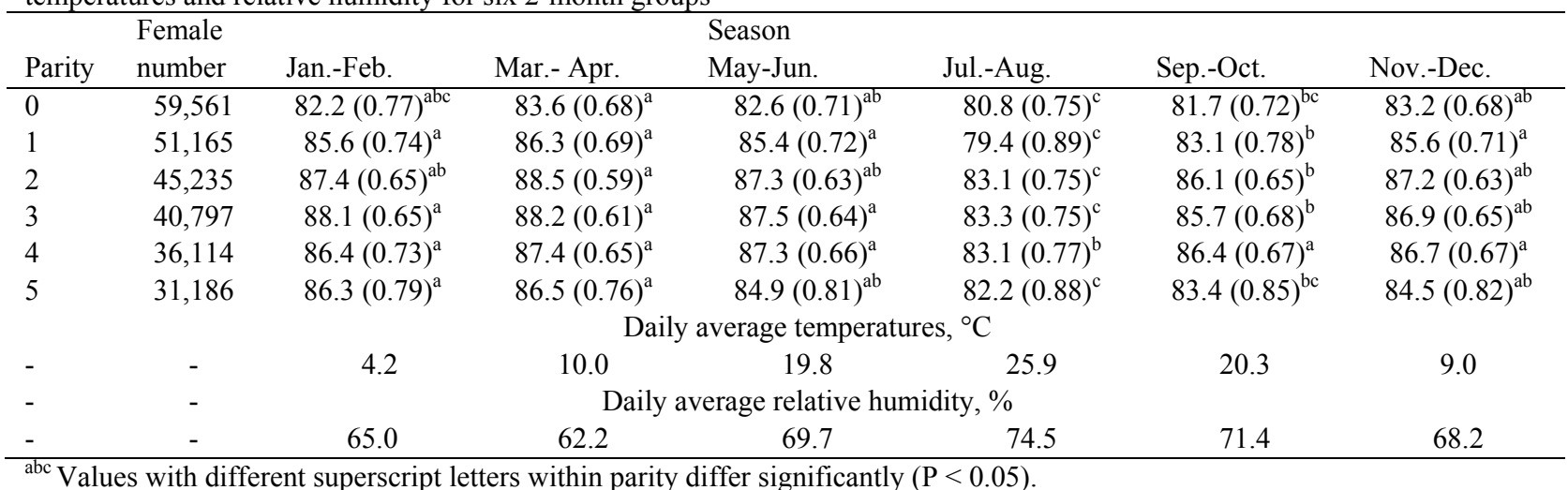


Lower farrowing rate in each parity group was associated with higher pre-service Tavg $(\mathrm{P}<0.01)$, but not with pre-service humidity ( $\mathrm{P} \geq 0.09$; Tables 3 and 4$)$. Farrowing rates of females in parities 0 and 1 non-linearly decreased from 82.9 to $79.6 \%$ and from 83.1 to $71.3 \%$, respectively, as pre-service Tavg increased from 15 to $30^{\circ} \mathrm{C}(\mathrm{P}<0.01$; Fig. 1). Over the same increase in Tavg, farrowing rates of females in parities $2-4$ decreased by $6.0-7.5 \%(\mathrm{P}<0.01)$, and the decrease for parity 5 females was from 85.1 to $80.0 \%$
$(\mathrm{P}<0.05)$.

Regarding the production factors, delayed age of gilts at first-mating and re-service occurrences were associated with lower farrowing rate in gilts $(\mathrm{P}<0.01$; Table 3). In sows lower farrowing rate was associated with WMI of 7 days or longer and with re-service occurrences $(\mathrm{P}<0.01$ Tables 3 and 4$)$, but not with lactation length $(\mathrm{P} \geq 0.06)$. With regard to the ICC, the random herd effect explained $3.7-5.4 \%$ of the total variance of farrowing rate in the final models.

Table 3. Estimates of fixed effects and random effect variance included in the final binary logistic regression models for farrowing rate in parities $0-2$.

\begin{tabular}{|c|c|c|c|c|c|c|}
\hline \multirow[t]{2}{*}{ Fixed effects and variance } & \multicolumn{2}{|l|}{ Parity 0} & \multicolumn{2}{|c|}{ Parity 1} & \multicolumn{2}{|c|}{ Parity 2} \\
\hline & Estimate $( \pm$ SE $)$ & P-value & Estimate $( \pm \mathrm{SE})$ & P-value & Estimate $( \pm \mathrm{SE})$ & P-value \\
\hline Constant & $1.6857(0.0431)$ & $<0.01$ & $1.9472(0.0505)$ & $<0.01$ & $2.1216(0.0475)$ & $<0.01$ \\
\hline $\begin{array}{l}\text { Mean daily average } \\
\text { temperature (Tavg), }{ }^{\circ} \mathrm{C}\end{array}$ & $-0.0066(0.0015)$ & $<0.01$ & $-0.0214(0.0016)$ & $<0.01$ & $-0.0169(0.0018)$ & $<0.01$ \\
\hline Tavg-squared & $-0.0005(0.0002)$ & $<0.01$ & $-0.0017(0.0002)$ & $<0.01$ & $-0.0014(0.0002)$ & $<0.01$ \\
\hline Re-service & $-0.9390(0.0287)$ & $<0.01$ & $-0.7052(0.0343)$ & $<0.01$ & $-0.9773(0.0400)$ & $<0.01$ \\
\hline WMI 7 days or longer & & & $-0.3696(0.0305)$ & $<0.01$ & $-0.5730(0.0379)$ & $<0.01$ \\
\hline $\begin{array}{l}\text { Gilt age at first-mating, } \\
\text { days old }\end{array}$ & $-0.0033(0.0005)$ & $<0.01$ & & & & \\
\hline $\begin{array}{l}\text { Number of pigs weaned, } \\
\text { pigs }\end{array}$ & & & $0.0196(0.0079)$ & 0.01 & $0.0449(0.0092)$ & $<0.01$ \\
\hline Herd variance & $0.129(0.024)$ & & $0.188(0.032)$ & & $0.149(0.027)$ & \\
\hline $\begin{array}{l}\text { Variance for serviced } \\
\text { years within herds }\end{array}$ & $0.031(0.008)$ & & $0.027(0.008)$ & & $0.025(0.010)$ & \\
\hline $\begin{array}{l}\text { ICC (records within the } \\
\text { same herd), } \%\end{array}$ & 3.7 & & 5.4 & & 4.3 & \\
\hline
\end{tabular}

WMI: weaning-to-first-mating interval; ICC: intraclass correlation coefficient.

Table 4. Estimates of fixed effects and random effect variance included in the final binary logistic regression models for farrowing rate in parities 3-5.

\begin{tabular}{|c|c|c|c|c|c|c|}
\hline \multirow[t]{2}{*}{ Fixed effects and variance } & \multicolumn{2}{|l|}{ Parity 3} & \multicolumn{2}{|c|}{ Parity 4} & \multicolumn{2}{|c|}{ Parity 5} \\
\hline & Estimate $( \pm \mathrm{SE})$ & P-value & Estimate $( \pm \mathrm{SE})$ & P-value & Estimate $( \pm \mathrm{SE})$ & P-value \\
\hline Constant & $2.1033(0.0474)$ & $<0.01$ & $2.0728(0.0477)$ & $<0.01$ & $1.8796(0.0517)$ & $<0.01$ \\
\hline $\begin{array}{l}\text { Mean daily average } \\
\text { temperature (Tavg), }{ }^{\circ} \mathrm{C}\end{array}$ & $-0.0160(0.0019)$ & $<0.01$ & $-0.0096(0.0020)$ & $<0.01$ & $-0.0143(0.0022)$ & $<0.01$ \\
\hline Tavg-squared & $-0.0013(0.0003)$ & $<0.01$ & $-0.0014(0.0003)$ & $<0.01$ & $-0.0007(0.0003)$ & 0.02 \\
\hline Re-service & $-0.9354(0.0437)$ & $<0.01$ & $-1.0748(0.0470)$ & $<0.01$ & $-1.0966(0.0529)$ & $<0.01$ \\
\hline WMI 7 days or longer & $-0.6061(0.0417)$ & $<0.01$ & $-0.6192(0.0460)$ & $<0.01$ & $-0.6825(0.0522)$ & $<0.01$ \\
\hline $\begin{array}{l}\text { Number of pigs weaned, } \\
\text { pigs }\end{array}$ & $0.0622(0.0097)$ & $<0.01$ & $0.0781(0.0101)$ & $<0.01$ & $0.0841(0.0105)$ & $<0.01$ \\
\hline Herd variance & $0.142(0.027)$ & & $0.133(0.027)$ & & $0.167(0.032)$ & \\
\hline $\begin{array}{l}\text { Variance for serviced } \\
\text { years within herds }\end{array}$ & $0.026(0.010)$ & & $0.031(0.013)$ & & $0.027(0.012)$ & \\
\hline $\begin{array}{l}\text { ICC (records within the } \\
\text { same herd), } \%\end{array}$ & 4.1 & & 3.8 & & 4.8 & \\
\hline
\end{tabular}

WMI: weaning-to-first-mating interval; ICC: intraclass correlation coefficient. 


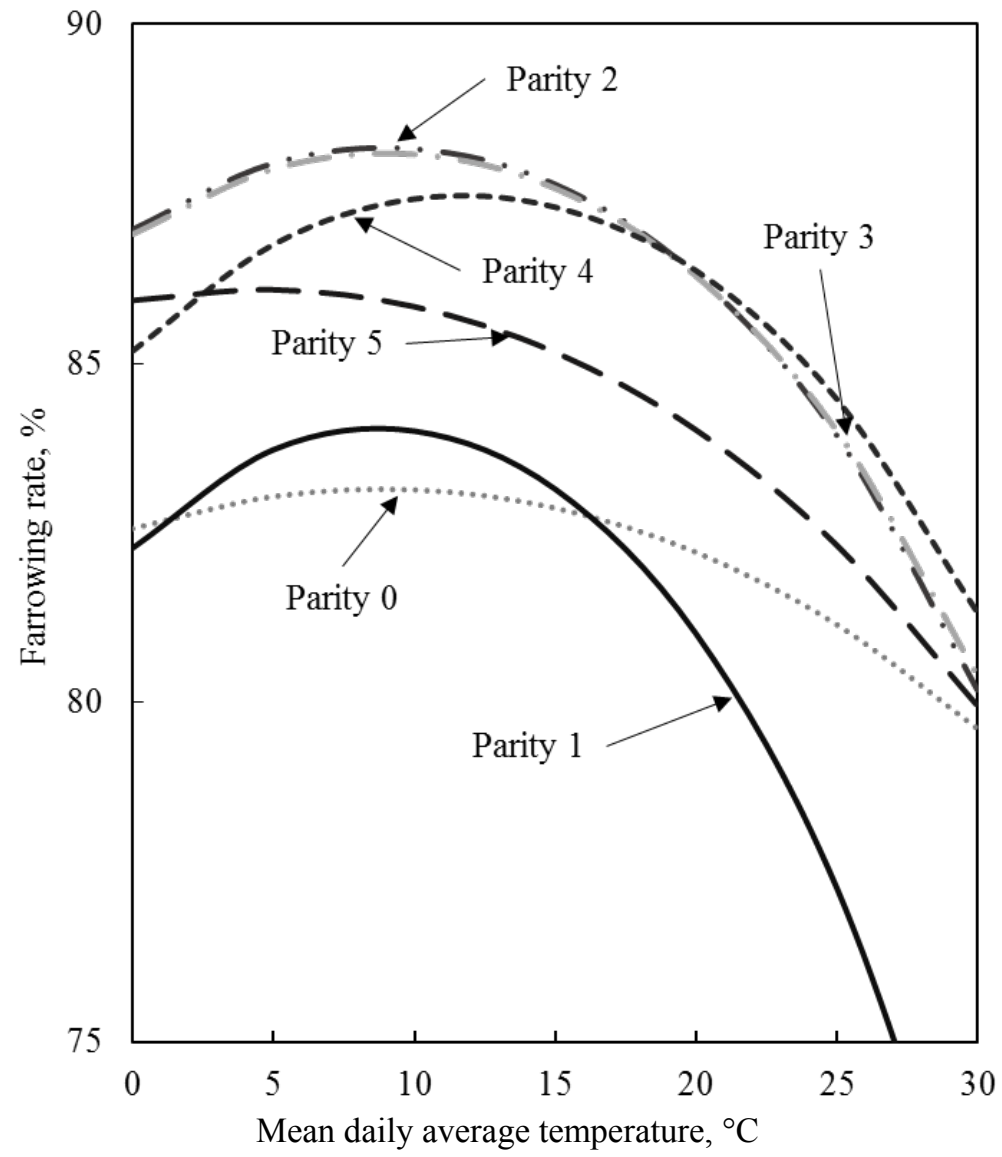

Figure 1. Predicted effects of mean daily average temperature during the 21-day pre-service periods on farrowing rate of females in different parities.

\section{Discussion}

The present study reveals quantitative associations between high outdoor temperature and farrowing rate or reproductive failure in female pigs in commercial herds. It has been hypothesized that seasonal pregnancy loss occurs due to a reduction in the release of luteinizing hormone during lactation, restricted follicle growth and development, and impaired pregnancy maintenance (Bertoldo et al., 2012). In a previous Thai study, it was shown that gilts and sows serviced in a hot season had a lower farrowing rate than those serviced in a cool season (Tummaruk et al., 2010). Another Spanish study also reported that farrowing rate for parity 2-7 sows in a Dutch purebred Yorkshire line was decreased as maximum temperature on the day of insemination rose above $19.2^{\circ} \mathrm{C}$ (Bloemhof et al., 2008).

Our study suggests that the negative association between high ambient temperature and decreased farrowing rate is more accentuated in primiparous sows than in gilts and multiparous sows. Primiparous sows have a low feed intake capacity, and the voluntary feed intake of these sows is commonly insufficient to meet nutrient demands for maintenance, milk production and body growth during lactation (Noblet et al., 1990). Furthermore, reduction in voluntary feed intake due to heat stress can be accentuated in primiparous sows more than in multiparous sows (Silva et al., 2009). Our study also shows that the highest farrowing rates in primiparous sows occurred when the outdoor temperature was approximately $10^{\circ} \mathrm{C}$. Therefore, we recommend that producers pay more attention to primiparous sows in summer.

It has been shown that the negative effect of high ambient temperature on sow performance, e.g., number of total pigs born, is emphasized when relative humidity becomes quite high (Iida and Koketsu, 2014). However, the present study showed no association between humidity and farrowing rate. Thus, there does not appear to be any significant direct effect of humidity during the pre-service period on reduced farrowing rate.

In our study, the reduced farrowing rates in gilts with prolonged ages at first-mating, in re-serviced females and in sows with prolonged WMI are consistent with previous studies (Takai and Koketsu, 2007; Kaneko et al., 2013). However, the lack of any association between lactation length and farrowing rate in our study is in contrast to previous studies (Takai and Koketsu, 2007; Bertoldo et al., 2009). The reason for the lack of any association in our study is probably because the random herd effect in our models could have explained some of the variation in lactation length. Finally, in the present study, the relatively low ICC of $3.7-5.4 \%$ for records within the same herds indicates that there was little herd effect on farrowing rate.

There are some limitations that should be noted when interpreting the results of this study. This was an 
observational study performed using commercial herd data and climate data recorded at meteorological stations. Therefore, herd health, nutrition, feeding program, genotype, the number of inseminations, and also boar fertility or service sire effects were not taken into account in the analyses. However, even with such limitations, this research provides valuable information about the quantitative relationship between climate factors and farrowing rate for swine producers and veterinarians. In addition, although this study did not collect herd temperature or the relative humidity in the commercial herds' breeding barns, a previous study showed that changes in the air temperature of farrowing barns were closely related to changes in external air temperature (Odehnalová et al., 2008).

In conclusion, we recommend that producers apply more advanced cooling management (e.g., evaporative cooling systems, chilled drinking water or floor cooling systems) to prevent a decrease in farrowing rate due to high temperature. Moreover, it is recommended that producers pay careful attention to higher aged gilts at first-mating, and also to sows with delayed WMI and to re-serviced females.

\section{Acknowledgments}

We gratefully thank the producers for their cooperation in providing their valuable data for use in this study, and also the staff at Global Pig Farms, Inc. (Shibukawa, Gunma, Japan) for their technical assistance. We also thank Dr. I. McTaggart for his critical review of this manuscript. This work was supported by the Giken Research Project Grant A 2012-2016 from Meiji University.

\section{References}

Bertoldo M, Grupen CG, Thomson PC, Evans G, Holyoake PK. 2009. Identification of sow-specific risk factors for late pregnancy loss during the seasonal infertility period in pigs. Theriogenology, 72:393-400.

Bertoldo MJ, Holyoake, PK, Evans G, Grupen CG 2012. Seasonal variation in the ovarian function of sows. Reprod Fertil Dev, 24:822-834.

Bloemhof S, van der Waaij EH, Merks JW, Knol EF. 2008. Sow line differences in heat stress tolerance expressed in reproductive performance traits. J Anim Sci, 86:3330-3337.

Bloemhof S, Mathur PK, Knol EF, van der Waaij EH. 2013. Effect of daily environmental temperature on farrowing rate and total born in dam line sows. J Anim Sci, 91:2667-2679.

Dial GD, Marsh WE, Polson DD, Vaillancourt JP. 1992. Reproductive failure: differential diagnosis. In: Leman AD, Straw BE, Mengeling WL, D'Allaire S, Taylor DJ (Ed.). Diseases of Swine. 7th. ed. Ames, IA: Iowa State Univ. Press. pp. 88-137.

Dohoo IR, Martin SW, Stryhn H. 2009. Veterinary Epidemiologic Research. 2nd. ed. Charlottetown,
Canada: VER Inc. 865 pp

Freitas MS, Misztal I, Bohmanova J, West J. 2006. Utility of on- and off-farm weather records for studies in genetics of heat tolerance. Livest Sci, 105:223-228.

Hoving LL, Soede NM, Graat EAM, Feitsma H, Kemp B. 2011. Reproductive performance of second parity sows: relations with subsequent reproduction. Livest Sci, 140:124-130.

Iida R, Koketsu Y. 2014. Interactions between pre- or postservice climatic factors, parity, and weaning-tofirst-mating interval for total number of pigs born of female pigs serviced during hot and humid or cold seasons. J Anim Sci, 92:4180-4188.

Japan Meteorological Agency (JMA). 2014. Climate Statistics (Japanese). Available on: http://www.data.jma. go.jp/gmd/risk/obsdl/index.php. Accessed on: Jan. 1, 2014.

Kaneko M, Iida R, Koketsu Y. 2013. Herd management procedures and factors associated with low farrowing rate of female pigs in Japanese commercial herds. Prev Vet Med, 109:69-75.

Lewis CRG, Bunter KL. 2011. Effects of seasonality and ambient temperature on genetic parameters for production and reproductive traits in pigs. Anim Prod Sci, 51:615-626.

Littell RC, Milliken GA, Stroup WW, Wolfinger RD, Schabenberger O. 2006. SAS for Mixed Models. 2nd. Ed. Cary, NC: SAS Institute Inc.

Noblet J, Dourmad JY, Etienne M. 1990. Energy utilization in pregnant and lactating sows: modeling of energy requirements. $J$ Anim Sci, 68:562-572.

Odehnalová S, Vinkler A, Novak P, Drabek J. 2008. The dynamics of changes in selected parameters in relation to different air temperature in the farrowing house for sows. Czech J Anim Sci, 53:195-203.

Peel MC, Finlayson BL, McMahon TA. 2007. Updated world map of the Köppen-Geiger climate classification. Hydrol Earth Syst Sci, 11:1633-1644.

PigCHAMP. 1996. Report manual for 4.0: PigCHAMP. St. Paul, MN: University of Minnesota.

Sasaki Y, Koketsu Y. 2011. Reproductive profile and lifetime efficiency of female pigs by culling reason in high-performing commercial breeding herds. J Swine Health Product, 19: 284-291.

Silva BAN, Oliveira RFM, Donzele JL, Fernandes HC, Lima AL, Renaudeau D, Noblet J. 2009. Effect of floor cooling and dietary amino acids content on performance and behaviour of lactating primiparous sows during summer. Livest Sci, 120:25-34.

Stevenson JS, Britt JH. 1981. Interval to estrus in sows and performance of pigs after alteration of litter size during late lactation. J Anim Sci, 53:177-181.

Takai Y, Koketsu Y. 2007. Identification of a female-pig profile associated with lower productivity on commercial farms. Theriogenology, 68:87-92.

Tummaruk P, Tantasuparuk W, Techakumphu M, Kunavongkrit A. 2010. Influence of repeat-service and weaning-to-first-service interval on farrowing proportion of gilts and sows. Prev Vet Med, 96:194-200. 